IJMS 23 (2), 83-95 (2016)

\title{
THE CONCEPTUAL FRAMEWORK FOR A SUSTAINABLE HALAL SPA BUSINESS IN THE GULF OF THAILAND
}

\author{
ORAPHAN CHANIN \\ Faculty of Business Administration \\ Rajamangala University of Technology Srivijaya
}

\begin{abstract}
This article aims to provide discussions on the sustainable halal spa business in the Gulf of Thailand by providing the framework indicating the factors affecting the service business offered to the Moslem tourists. The article highlights the high potential of halal spa business, although it may have a negative connotation for Moslem tourists, by providing for the needs of Moslem tourists in the Gulf of Thailand and the services offered by a number of spa operation that claim to be halal spa business. The article discusses and provides the theoretical concept and practices by highlighting the potential factors affecting those halal spa businesses, from the perspective Thailand spa operators. Focusing on the internal and external elements, the factors affecting the service of halal spa businesses in the Gulf of Thailand for Moslem tourists are presented within the common components of product, price, place, promotion, people, process and physical evidence. It is suggested that the potential for halal spa business in the Gulf of Thailand is high and the information provided can improve the promotion and sustainability of the halal spa business model in enhancing the tourism sector in Thailand.
\end{abstract}

Keywords: Sustainability, Halal spa business, Moslem tourist, Gulf of Thailand.

Received: 07/07/2016 Revise: 27/09/2016 Accepted: 02/11/2016 Publish: 15/12/2016

\section{Introduction}

Nowadays, tourism is an important industry that contributes to the economy of a country (Hamira \& Joan, 2010). In other words, many countries around the globe have recognized tourism as a service industry that significantly contributes to their economic development. According to Korres (2008) a successful tourism industry can stabilize a country's economy, offers job opportunities to the local people and makes the country known to the world. It also provides value 
to the society and the environment (Ecological Tourism in Europe and UNESCO-BRESCE, 2009). According to Pacific Asia Travel Association (2015), the tourism industry is a dynamic and pervasive industry. It has a wide range of benefits and contributions to all parties that participate in the industry.

In many regions worldwide, countries are competing to attract tourists to choose their country as the tourist destinations (Ecological Tourism in Europe \& UNESCO-BRESCE, 2009). The operators and the governments together are competing with the other counterparts to attract tourist. The authorities are making heavy investment in the industry. They want to compete with their rivals by setting up strategies that can respond to the tourists' needs (Halbase, 2011). Tourists that travel around inside the country are valuable 'ambassadors' to promote the places and the countries they have visited. Knowing that tourists that visit the country may repeat their visit and may bring or convince others to visit the places interest, such investment is worth the effort.

Tourists in Thailand come from all parts of the world. There is a drastic increase in number of tourists from the Middle East are coming to Thailand in the recent years. They are mostly Moslem who require halal tourism services. The number of tourists from the region travelling to Thailand is still small, averaging at 476,024 people each year in the last 5 years (Thai Post, 2013). However, looking at the number of Arab tourists to Malaysia, reportedly at Tourism Authority of Thailand, 2013 for the year of 2014 and 2015 respectively, there is a tendency for them to extend their visit to Thailand as tourists. Moreover, there are Moslem tourists from the neighboring countries like Malaysia and Indonesia. Since Thailand became a member of the Asean Economic Community (AEC), it has had an increased number of tourists from Moslem countries in South East Asia such as Malaysia, Indonesia, and Brunei travel to Southern Thailand (Institution for tourism professional training, 2011). This is a huge potential for the tourism industry in Thailand.

\section{The Spa Business In Thailand And The Potential Of Halal Spa Business}

In Thailand, the spa business is one of the 'killer' attraction for the country's tourism industry. Tourists from all over the world are coming to visit the country, to a number of tropical tourist locations are offered innovative and creative services to ensure tourists are satisfied with their stay in Thailand. One of the available services related to 
this industry is the spa business. However, the spa business is always associated with the non-halal activities (Prachachat Business, 2015) and thus this business is viewed for the non-Moslem and the local people. Whilst the halal tourism concept is proposed, a relatively new kind of tourism service in the tourist industry that focuses on the target group of tourists from Moslem countries, the halal spa business must be developed in order to meet the needs of this new market of tourists.This can be done by providing spa services that can respond to their needs by providing services which are in line with their religious practices (Sriprasert, Chanin \& Rahman, 2014). It is like the other services such as hotel business where hotels may support Moslem tourists by providing products and services free of prohibited goods such as pork meat and alcoholic drinks. In addition, the swimming pool, massage room and prayer room need to be separated for men and women (Halbase, 2011).

The spa business is a legal and common business in Thailand. It covers steaming and sauna, massage and reflexology and the untold 'added value leisure' that is widely known in this country. The massage and reflexology are the popular services to tourists coming to Thailand. Most of the therapists are young ladies between the age of 20 to 40 who are well trained and certified by the authority. The service ranges from basic sauna to full body massage that take about one hour to four hours per session with the cost from BTH300 per hour. This is considered as the legalized cheapest rate in the region even when compared to the rate in Indonesia and The Philippines (Prachachat Business, 2015).

According to the report by Tourism Authority of Thailand (2013), $43 \%$ of the tourists from the Middle East era countries use the service available at the spa business centers. The report also indicates that these tourists have ranked spas on the top of their list of activities, spending about BHT3,918 per trip on average. It totals to BHT826 million, accounts for $5 \%$ of the total market value with the total yearly profit of BHT16,000 million (Prachachart Business, 2015). In view of this, the Thai government has given a great attention to the potential of halal tourism activities, including the halal spa business. The idea is to start with the raw material quality to be in accordance with Islamic principles and move on to the interaction between clients and operators. For example, the cosmetic products for use in a halal spa business such as oil for massage, washing products and skin care products are free from any non-halal sources (from pork or made by through processes that are not in line with the religious principles). 
If Thailand wants to encourage more tourists from Moslem countries to visit the Kingdom, especially tourists from the group of Asean countries including Malaysia, Indonesia, and Brunei, it is neccessary to provide adequate halal spa services which are suitable for the needs of Moslem tourists. The approach to ensure products used in the spa business are halal seems to be gaining confidence from the Moslem tourists, although some of the products lack of the International for Standardisation Organisation, (ISO). Thai herbal and organic products are the answers for the halal queries. Both products are regarded as the heart of the halal spa business for moslem tourists. Apart from the cosmetic products used in spas, the process of providing the halal services is also given attention (The Halal Institute of Prince of Songkhla University, 2015). Male therapists are made available in most of the spa centers. This attracts many Moslem tourists that try to avoid female therapists to massage them.

The IMT-GT agreement that involved Indonesia, Malaysia and Thailand that focusses on the economic growth triangle development in Sumatra, Indonesia Northern, West Malaysia and Southern Thailand makes the research focus on the Gulf of Thailand more relevant. The area included in the Gulf of Thailand comprising of Chumphon, Surat Thani, Nakhon Sri Thammarat and Phatthalung provinces are mainly in the Southern Thailand area. Through this cooperation, the number of tourists from Malaysia and Indonesia coming to Thailand can be far higher than in the past (Nittaya, 2008). According to the data from the Department of Tourism, it was found that tourists from Malaysia, which are at $17.5 \%$ of the total number of tourists, travel to Thailand and spend most of their time in the South. They can mostly be found in the city of Hatyai in Songkhla province, the center of the Southern Thailand. The statistics from the Department of Tourism, Thailand shows that the number of tourists travel into Thailand from/through Malaysia are ranked second highest every year for the year 2000 to 2010 (Department of Tourism, Thailand, 2011)

\section{Halal Spa As A Small Business}

Most of the spa businesses in Thailand are managed by small operators. According to The Halal Institute of Prince of Songkhla University (2015), these businesses should fall into the category of small business. Lucky and Minai (2011) and Minai, Ibrahim and Law (2012) suggest to look into the performance of the small firm from the perspective of the operators, the business and the environment effecting on the businesses. The view is considered as more relevant 
compared to the common view of the internal and external forces as it offers a more details constructs and easy to relate to the spa business activities. Thus, based on this suggestion, the success factors of the halal spa business are viewed from the three perspectives.

The influence of operators is critical as they determine the management and operation of the business (Okhovat, 2010). They are the one that decide to have the normal or halal spa business. They have the final say and the flexibility that have is to the extent that they can operate halal and normal spa business according to their wish as the law in Thailand regarding the halal issues is not as strict as in other countries such as Malaysia. Moreover, the business of halal spa is quite unique as the negative connotation of the business to the Moslem. The premises are often found in the hotels, secluded and private areas that allow the free mix between genders without covering the way in the dress code of the Moslem.

With regard to the environment affecting the halal spa business, most of the common factors affecting the success of small businesses remain important. This must be viewed from the small business perspective and with the help of the bigger organization, for example, the government body that taking care of the tourism industry. As the service industry, marketing and promotion are crucial (Department of Tourism Thailand, 2011), the individual marketing capabilities can be limited. Thus, the environment affecting the halal spa business requires differences and will be discussed later.

\section{The Methodology}

The article is written based on the unstructured discussions and interviews with the spa business operators and Moslem tourists visiting Thailand. The interviews took place in the Southern region of Thailand, at Songkhla, Phuket and Surat Thani. They were done in January 2016 involving five spa operators and ten Moslem tourists. All interviewed spa operators are operating the normal spa and two of them have expressed their intention to become halal spa business.

This research is qualitative in nature, as suggested by Yin (2003), however, with the guided model provided by Lucky and Minai (2011). In terms of the respondents, the Moslem tourists are from Middle East (three persons), from Malaysia (four persons) and from the undisclosed countries ( 3 person). All are male tourists with the age above 30 years old. 


\section{The Contributing Factors Towards The Sustainablity Of A Halal Spa Business}

The contributing factors toward sustainable halal spa business are viewed from the three dimensions proposed by Lucky and Minai (2011), which are (i) the owners and the operators (ii) the nature of spa business and (iii) the environment affecting the spa business. The discussion is guided by the theory of maketing components by Kotler comprising the marketing mix 7's (Kotler, 2011) and the model of environment effecting the small business proposed by Sureerat (2015).

\section{The owners and operators:}

It is cited by one of the respondent that "the staff who look after the Moslem tourists should also be Moslem". This statement indicates the importance of the owners or operators to know about Islam. Whilst they don't have to be a moslem, understanding what is permissible and what is prohibited in the religion is very important. The service must be in line with the Islamic principles. It is important to ensure the operators who are familiar with the Islamic principles regarding human physical interaction on top of the other criterias such as proper training, cleaness and health safety. This is evidenced from the quotation given by another respondent "halal spa needs to have all the qualities available at the normal spa, however, needs the service to be adjusted according to the religion perspective".

\section{The nature of spa business:}

(a) The Service Factor: The operation of the spa business nowadays provides a diverse range of services including herbal steam, whirpool water-jet bathing (Jacuzzi), thai ancient massage, oil massage and relaxing massage. The context of the service remains the same, however, the services need to be conducted different from the current practices (Rostam, Zarina \& Nurishahaini, 2012), for example, male masseuse to service male tourists and female masseuse to service female tourists. The following statement is quoted "in Islam, nonMuhrim can not do the massage service". The halal spa must avoid selling alcohol drinks and must definitely not have sexual services on offer.

The products and equipments used for the spa service must also comply to the syariah laws. Soaps and lotions must be from the halal products. According to one respondent, "halal product is a must, 
product must not contain non-halal component, in particular, ingredients of pork by-products. The Moslem like from Malaysia are really concerned about pork by-products".

(b) The Price Factors: there is no issues regarding pricing to the Moslem tourists. They are said to be generous and usually pay in cash. There is a concern about credit card payment, a type of payment that a small group of them argue that it is not halal. One respondent said "the use of credit card should be avoided as some Moslem think it is not halal". However, with the Islamic credit card, this is not an issue to be concern with.

(c) The Location Factor: It is found that the Moslem tourists are a little skeptical when they are driven to a remote and hidden places when going for spa services. Some are said to be reluctant to go to the places that are inside temple or prayer places. "halal and temple, oh no, they are contradicting", said one of the respondent. The location of the spa must be away from the non-Moslem prayer places and places with porcine and alcoholic related activities.

As the spa service might take a few hours, Moslem tourists, at certain time, need to offer prayers. It is thus advisable for the halal spa business to prepare a place for the tourists to pray. According to one of the respondent, "Moslem tourists need to pray when the prayer time comes, however, they can pray at the mosque". However, at the Gulf of Thailand, there are a lot of mosques and this makes the prayer room not necessary as they can pray at the mosque.

(d) The Physical Factor: there is a need to segregate the male and female customers when comes to giving the service. Cubical segregation only is not enough where a separate location is needed, for example, in adjacent buildings or on different floors. One of the respondent cited, "our religion asks for the segregation between men and women that are not blood related when come to the activities that expose certain part of their bodies".

(e) The Promotion factor: one of the criteria regarding promotions is that it follows the Islamic guideline in advertising (Mohammad \& Mohammad, 2013). Moreover, according to one of the respondent, "Moslem are attracted to the poster showing the halal food and service that they can get". For example, there is a need to avoid advertising women as the model and mixing with the prohibited services. Another respondent mentioned about the use of certified halal logo, which is to be encouraged. 
(f) Safety factors: Halal spa business should be located in an area where the local environment is safe. The hygenic practices are of utmost importance as the halal concept is closely related to these practices. The practices include the use of new gloves for each customer, fresh and clean towels and bedsheets. Although these factors are generic factors to spa business, the safety factors are included as they are the concern back in their counries. There are countries in the Middle East that do not allow their citizen to enter Thailand and if found, they are bound for the medical tests back home. A respondent said, "this is due to the reputation of the country and we need to go for HIV tests upon returning from Thailand, if the immigration 'catch' us".

\section{The environment affecting the spa business:}

The analysis on the environment affecting spa business was finalized with four factors to be considered in examining the success or the sustainability of the business. They are (i) the social, cultural and demographic factors, (ii) the environmental sustainability factor, (iii) the legal, political and governmental factors, and lastly (iv) the technological factors.

The social/cultural/demographic factors: The factors under the social, cultural and demographic factors are one of the important dimensions representing the environment affecting the spa business. The social and cultural factors are very much different between the people in Thailand and the tourists from Middle East and neighbouring countries where majority of their citizen are Moslem. The change of cultural and social behaviour is very difficult, however, understanding the tourist cultures can bring business to Thailand people. Thus, paying attention to the tourists cultures is required. A respondent is quoted as saying, "culture tolerance is important, as we must assume customers is alway right, we need to fulfill their needs, moreover, they come to our country and we need to provide what they want. if they want halal spa, we give as long as we our business prosperous".

Many of the Southern of Thailand people are Moslem. These people have almost similar culture and there is a possibility to develop 'special' relationship between Moslem tourists and the local Moslem community. Moreover, the memorable spa services make the tourists remember and can also assist in supporting the promotion of local products, especially halal food industry. It is an interrelated activities where when tourists will look for food, Moslem tourists look for halal food. According, the following quote is referred to, "Moslem are very particular about non-pork food, even though they drink alcohol and enjoy 
non-halal spa. However, the new trend shows that they are now more concern about everything halal".

These factors especially relate to the promotion and preservation of the local culture and folk customs. The local social culture can be promoted on top of the wellknown Thailand culture. There are many mosques associated with the local Moslem where information regarding mosques when the tourists want to offer prayers can be obtained from the halal spa businesses.

The environmental sustainability factors: The environmental sustainability factors are related to the halal spa in the form of halal products being used during spa services. The use of products that are eco-friendly and the use of herbal products is always seen as halal products. Natural products are easily classified as halal or non-halal as compared to the process products where the list of ingredients needs to be supplied before the products can be described as halal. Thus, the use of halal product, for example, herbal products, provide advantages to the halal spa business. "if halal spa can bring good to the environment, this business has a very good future", said one of the respondent.

Legal/political/governmental factors: Halal concept is also viewed from the country is legal policies besides the religious perspective. Most of the tourists including Moslem tourists go for legal businesses. Thus, the spa operator must have proper operating licence from the government before it can claim to be the halal spa operator. "the illegal spa operation should be considered as non-halal spa business, isn't it?" This is a question ask by a respondent. Whilst it might not be the right answer, it is appropriate to have the permission from the government before operating the spa business, and then claim it to be halal spa business.

Technological factors: The factors related to technology are actually grey areas. A number of respondents suggest that technological factors such as video recording, surveillance and monitoring invade privacy and exposure of the spa activities may lead toward the halal spa business become otherwise.

\section{Conclusion}

From the above discussions and the insights from the respondents comprising the spa operators and the authorities of the local tourism 
centers, the following diagram depict the conceptual framework for the factors contributing to the sustainable halal spa business in the Gulf of Thailand.

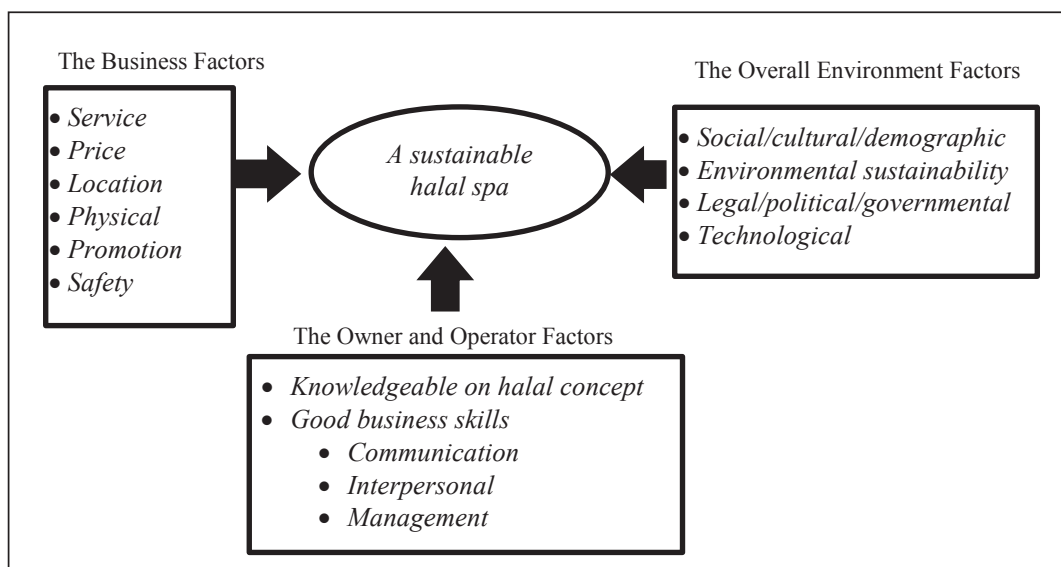

Figure 1. Factors contributing to the Sustainable halal spa business

In order to take advantage on the increasing number of Moslem tourists in Thailand, the spa business operators have to ensure their operation to be halal and according to the Islamic principle so that these tourists are comfortable when receiving the spa services. First, they must convince the tourists that they comply and understand the Moslem way of offering the spa services to the clients, though they do not have to be a Moslems. On top of being friendly, polite and sociable, the operators must wear a proper uniform which is modest and in line with Islamic principles. For example, the masseur should be a professional without going further than providing massage services such as giving the 'extra' services. The Moslem spa business owners may have the advantages in providing the spa services as the trust between Moslem tourists and operators is higher. For example, many male Moslem tourists look for male masseurs and female look for female masseuse. The signboard suggesting such service from by a Moslem operator may attract the Moslem tourists to get the service.

It is notable that the ability to speak Arabic and Malay give extra advantages to operate halal spa business. This is on top of the ability to communicate in English. There should be at least one person to be able to speak the language of Moslem tourists to be able to explain 
about the available service, how the service is being offered and the actions or measures being practiced are halal compliance. This sumsup the importance of owner and operator factors. They can make a significant impression on Moslem tourists who may then spread the word of their positive experience to other tourists as well as those tourists returning for the repeat customers in the future

Second, understanding and practicing the halal spa business are crucial in attracting Moslem tourists. The halal spa business must be distinguishable and separated from the normal spa business. The halal spa business must strictly follow the halal concept and should move toward halal certification and supervision. Pricing of halal spa business should be the same as the normal spa business to ensure competitiveness. Promotion needs to be done to highlight the differences between halal and normal spa businesses.

Finally, the overall environment affecting the halal spa business must be examined and audited from time to time. The social and cultural aspects of both local people and tourists should tailor toward improving awareness and acceptance levels of halal spa business. The halal spa business needs to follow the general practices to ensure the environment is protected. The relevant authorities in Thailand should provide clear guidelines as related to the halal spa business. Lastly, the technology needs to be used for proper and permissible purposes.

These factors identified in Figure 1 can help the halal spa business in Thailand become sustainable. The increase in number of the Moslem tourists from the Moslem countries travelling to the Gulf of Thailand offers the potential clients for halal spa services. The Middle East countries are regarded as the countries that have high puchasing power and thus their present in Thailand can bring about an increase in halal spa business revenue. Consequently, it will have a good effect on the tourism industry in Thailand. It is predicted that there will be an increase in the number of Moslem tourists that make the trip to Thailand each year, therefore increasing the revenue streams from tourism industry throughout the Kingdom.

\section{Acknowledgement}

The author would like to thank the Faculty of Business Administration, Rajamangala University of Technology Srivijaya for supporting the author in conducting the study that enable the writing of this article. 
Also, I would like to express my gratitude to Associate Professor Dr. Hamzah Dato Abdul Rahman and Associate Professor Dr. Ali Yusob Md Zain at the College of Business, the Universiti Utara Malaysia for their guidance and assistance. In addition, I would like to acknowledge my parents and friends for their continuous support and assistance.

\section{References}

Department of Tourism. (2011). The indicators of the service quality of halal food for tourism, Bangkok. Retrieved from http://www. tourism.go.th

Ecological Tourism in Europe \& UNESCO-BRESCE. (2009). Stainable tourism training the trainers programme. Retrieved from http:// www.unesco.org/new/en/venice/special-themes/sustainabletourism/

Halbase. (2011). Halal Tourism.Working Paper. Retrieved from http:// halbase.com/articles/ Halal\%20Tourism.pdf.

Hamira, Z. F. \& Joan,C. (2010). Islamic tourism and managing tourism development in Islamic societies: The cases of Iran and Saudi Arabia. International Journal of Tourism Research, 12, 79-89.

Korres, G.M.(2008). The role of innovation activities in tourism regional growth in Europe tourisms. International Multidisciplinary Journal of Tourism, (3)1, 135-152.

Kotler, P. (2011). Marketing Management. 11 st (ed). New Jersey : Person Education Indochina Ltd.

Lucky EOI \& Minai MS (2011). The conceptual framework of entrepreneur and self management. International Journal of Business and Social Science, 2(20), 180.

Minai, Ibrahim \& Law (2012). Entrepreneurial network in Malaysia: Are there any differences across Ethnic Groups? Journal of Business and Policy Research, 7(1), Special Issue178 - 192.

Mohammad E. Islam \& Mohammad Z. A. (2013). Advertising: An Islamic perspective. International Journal of Ethic in Social Science, 1(1)

Nittaya, T. (2008). The custom and Foreign Affair. Retrieved from http:// www. sadaocustoms.org/index.php?lay=show\&ac=article\& $\mathrm{Id}=539263099$

Okhovat, H. (2010). A study of religious tourism industry management case study: Islamic Republic of Iran. International Journal of Academic Research, 5(2), 302-307.

Pacific Asia Travel Association. (2015). Contribution of toursim. Retrieved from http://sustain.pata.org/sustainable-tourism- 
online/destinations-and-communities/destination-planning/ situation-analysis/contribution-of-tourism/

Prachachat Business. (2015). "Halal spa" The individual exploring the marketing channels for the standard to support. Retrieved from http://m.prachachat.net/news_detail.php? newsid $=1424327162$

Rostam Y, Zarina A. \& Nurishahaini. (2012). Beauty treatment and spa design from Islamic perspective. Procedia- Social and Behavioral Science, 50, 492-501.

Sriprasert, P., Chanin, O., \& Abdul Rahman, H. (2014). Understanding behavior and needs of Halal tourism in Andaman Gulf of Thailand: A case of Asian Muslim. Journal of Advance Management Science, 2(3), 216-219.

Sureerat, C. (2015). Increasing Halal tourism potential at Andaman Gulf in Thailand for Muslim country. Journal of Economics, Business and Management, 3(7), 739-741.

Thai Post. (2013). Tourism authority of Thailand: The invasion of getting the tourists from Middle East countries. Retrieved from http:// www.thaipost.net/news/060213/69119.

The Halal Institute of Prince of Songkhla University 2015. Halal Spa Business. Retrieved from http://www.halinst.psu.ac.th/th/ knowledge-th/halalarticle-th/135-2011-0530-14-55-31.html

Tourism Authority of Thailand. (2013). Annual report 2012. Retrieved from http://thai.tourismthailand.org/about-tat/annual-report

Yin (2003). Case study research: Design and methods. 